\title{
Combined p21-activated kinase and farnesyltransferase inhibitor treatment exhibits enhanced anti-proliferative activity on melanoma, colon and lung cancer cell lines
}

Giampiero Porcu', Ainslie B Parsons², Daniele Di Giandomenico', Giuseppe Lucisano ${ }^{3}$, Maria Giovanna Mosca', Charles Boone ${ }^{2}$ and Antonella Ragnini-Wilson ${ }^{1,4^{*}}$

\begin{abstract}
Background: Farnesyltransferase inhibitors (FT/S) are anticancer agents with a spectrum of activity in Ras-dependent and independent tumor cellular and xenograph models. How inhibition of protein farnesylation by FTIs results in reduced cancer cell proliferation is poorly understood due to the multiplicity of potential FTase targets. The low toxicity and oral availability of FTIs led to their introduction into clinical trials for the treatment of breast cancer, hematopoietic malignancy, advanced solid tumor and pancreatic cancer treatment, and Hutchinson-Gilford Progeria Syndrome. Although their efficacy in combinatorial therapies with conventional anticancer treatment for myeloid malignancy and solid tumors is promising, the overall results of clinical tests are far below expectations. Further exploitation of FTls in the clinic will strongly rely on understanding how these drugs affect global cellular activity.

Methods: Using FTase inhibitor I and genome-wide chemical profiling of the yeast barcoded deletion strain collection, we identified genes whose inactivation increases the antiproliferative action of this FTI peptidomimetic. The main findings were validated in a panel of cancer cell lines using FTI-277 in proliferation and biochemical assays paralleled by multiparametric image-based analyses.

Results: ABC transporter Pdr10 or p-21 activated kinase (PAK) gene deletion increases the antiproliferative action of FTase inhibitor I in yeast cells. Consistent with this, enhanced inhibition of cell proliferation by combining group I PAK inhibition, using IPA3, with FTI-277 was observed in melanoma (A375MM), lung (A549) and colon (HT29), but not in epithelial (HeLa) or breast (MCF7), cancer cell lines. Both HeLa and A375MM cells show changes in the nuclear localization of group 1 PAKs in response to FTI-277, but up-regulation of PAK protein levels is observed only in HeLa cells.

Conclusions: Our data support the view that group I PAKs are part of a pro-survival pathway activated by FTI treatment, and group I PAK inactivation potentiates the anti-proliferative action of FTIs in yeast as well as in cancer cells. These findings open new perspectives for the use of FTIs in combinatorial strategies with PAK inhibitors in melanoma, lung and colon malignancy.
\end{abstract}

Keywords: Farnesylation, PAKs, Cancer, Yeast, Anti-cancer drug screening

\footnotetext{
* Correspondence: ragnini@negrisud.it

'Department of Translational Pharmacology, Consorzio Mario Negri Sud, S.

Maria Imbaro, Italy

${ }^{4}$ Department of Biology, University of Rome Tor Vergata, Rome, Italy

Full list of author information is available at the end of the article
} 


\section{Background}

Farnesyltransferase inhibitors (FTIs) are broad-spectrum low-toxicity anticancer agents originally isolated from fungi to inhibit Ras oncoprotein membrane attachment and therefore their malignant transforming activity $[1,2]$. The FTI Manumycin A was the first to be selected using a yeast-based genetic screen $[3,4]$. More than two decades of studies, using structurally different FTI compounds tested on several tumor cell lines, xenograph and cancer animal models, have confirmed that they act via evolutionarily-conserved mechanisms by inhibiting farnesyltransferase activity [1,2,5-7]. Surprisingly, FTIs were found to be effective also in Ras-independent tumors. Despite several studies, how FTIs act as antireplicative compounds remains to be fully elucidated: hundreds of proteins are farnesylated in human cells, among which are several proteins activating pro-survival pathways. Inhibition of farnesylated proteins such as RheB or CENP$\mathrm{E}$ appears to be among the consolidated data for some non-Ras tumors sensitive to FTIs. Complicating this picture, recent data suggest that farnesylation-independent pathways might also participate in the anticancer activity of FTIs [8-10].

Despite this lack of knowledge, the low toxicity of FTIs for normal cells and their wide-range of high antiproliferative action on tumor cells led to the introduction of orally-available FTI molecules into clinical trials [5,6,11]. The FTI Tipifarnib (Zarnestra, R115777) has been evaluated for the treatment of myeloid malignancy, including for elderly patients with acute myelogenous leukemia (AML) [6,12]. Moreover, Tipifarnib has shown promising results in coadjutant therapies for breast cancer [13]. The FTI Lonafarnib have shown efficacy in melanoma cells that develop resistance to Sorafenib, a pan-Raf inhibitor [14]. The poor performance of FTIs at the clinical level compared to their anticipated wide use in anticancer therapy clearly shows the weakness of the mechanistic studies performed thus far. The further exploitation and future introduction of FTIs into clinical therapy will largely depend on the identification of compounds that increase FTI antiproliferative action in resistant tumors and on the identification of susceptibility prediction markers $[5,6,11]$.

The major limitation of proteomic approaches undertaken thus far devoted to clarifying which farnesylated proteins are differentially prenylated upon FTI treatment has been the difficulty of correlating the effective protein prenylation status with their anti-proliferative action $[5,6]$. Several types of genomic technologies have been used to identify predictive markers/pathways that could explain how FTIs affect cellular activity and responsiveness. A handful of genes has been identified whose function might lead to FTI resistance [6,15-17]. Lack of FTI responsiveness has been shown to result from innate or acquired resistance or from FTI-mediated activation of pro-survival pathways. In addition, mutation of FTase or target genes, activation of alternative prenylation pathways, or changes in the balance of prenylated proteins have been described extensively upon FTI treatment [5,6,11].

To identify the major protein networks responding to FTI peptidomimetics as well as the major pathways that allow an escape from the anti-proliferative action of FTIs in yeast and mammalian tumor cell lines, we used budding yeast cell-based "omic" approaches and then validated the main findings in mammalian cancer cell lines. Well-characterized structurally related FTI compounds that are active in yeast or in mammalian cells, FTase inhibitor I and FTI-277, respectively, were used in order to compare the data. We expect that the basic knowledge obtained by these studies will give a better view of how to use clinically useful FTIs in combinatorial therapies. With this long-term goal in mind, in a previous study we profiled gene expression upon FTase inhibitor I treatment of yeast cells. Transcriptional and localization changes of P-glycoproteins belonging to the ABC transporter family acting in sphingolipid metabolism and drug resistance were observed [10]. Other transcriptional changes were found for genes encoding proteins that act in key signal transduction pathways regulating cell cycle entry and chromosome segregation and nutritional cues. We showed that these effects were specific to FTase inhibitor I (not being related to GGTase I inhibition or FTase subunit gene deletion in yeast cells). Multiparametric functional studies were carried out in HeLa cells to validate these observations. Nuclear morphology, Aurora A localization and S6 phosphorylation were found to be affected by FTI-277 treatment of HeLa cells [10]. Collectively these findings showed that FTIs have several unexpected effects on signaling pathways regulating proliferation that are not directly related to farnesylation and that these effects could be reciprocated in HeLa cells.

To identify genes whose deletion increases the antiproliferative action of FTI peptidomimetics, here we report the chemical-genetic profiling of the yeast Saccharomyces cerevisiae barcoded deletion strain collection using FTase inhibitor I. Two p-21 activated kinases (PAKs), Cla4 and SKM1, and the ABC transporter Pdr10 were among the genes whose deletion increased FTI sensitivity in yeast cells. To test whether PAK inhibition might increase FTI sensitivity in cancer cell lines resistant to FTIs, we measured the proliferation of HeLa, melanoma (A375MM), lung (A549), colon (HT29) and breast (MCF7) cancer cell lines after FTI-277 treatment, administrated alone or in combination with a highly selective group I PAK inhibitor, named IPA3 $[18,19]$. We show that the use of IPA3 at concentrations ranging from 5 to $7 \mu \mathrm{M}$ in combination with $5 \mu \mathrm{M}$ FTI-277 potently inhibits proliferation of A375MM melanoma, A549 lung and HT29 colon cancer cell lines, 
but hardly affects the proliferation of HeLa or MCF7 breast cancer cell lines.

\section{Results}

The ABC transporter Pdr10 and p-21 activated kinases act in pro-survival pathways mediating FTI peptidomimetic susceptibility in yeast cells

To identify genes promoting survival to FTI peptidomimetic treatment in eukaryotic cells, we performed a genome-wide drug sensitivity screen using the barcoded yeast deletion mutant collection (representing approximately 4700 genes) and $10 \mu \mathrm{M}$ of the peptidomimetic FTase inhibitor I (Calbiochem-MERK). We have shown previously that $10 \mu \mathrm{M}$ FTase inhibitor I treatment of BY4741 cells induces specific changes in the yeast transcriptome without affecting Ras binding to the plasma membrane [10].

The genome-wide sensitivity screen highlighted sixty-four genes whose deletion results in a two-fold increase in FTI sensitivity $(\log 2$ ratio $>0.5$, $p$-value $<0,05$; Additional file 1: Table S1). These sixty-four hits were further classified according to Gene Ontology criteria using the Super GO-Slim Process clustering tool available at the GO-SGD database (www.yeastgenome.org). This analysis showed that $25 \%$ of the genes promoting survival to FTI peptidomimetic treatment act in transport and $15.6 \%$ are annotated as being involved in cell cycle processes (Figure 1A; Additional file 2: Table S2). The functional associations among the hits involved in transport were further analysed using STRING (version 8.3, http://string.embl.de/). This analysis showed that Pdr10, an ATP-binding-cassette (ABC) transporter belonging to the multidrug resistant (MDR) gene class, and the PAKs CLA4 and SKM1 form a gene network with the ABC transporter PDR5 and the PDR transcriptional regulator PDR1 (Figure 1B).

We showed previously that PDR5 and PDR1 are transcriptionally up-regulated and that Pdr5 recycling increases in FTase inhibitor I-treated yeast cells [10]. Moreover, Pdr5 recycling depends on END4 [20], which interacts with the PAK Cla4p [21], suggesting the existence of a functional network that connects PDR5 recycling at the plasma membrane and PDR1 transcriptional upregulation upon FTI drug treatment with increased sensitivity in the presence of a CLA4 or PDR10 gene deletion.

To test this idea, we determined the levels of Cla4p and its state of phosphorylation in yeast cells expressing a GFP-tagged version of Cla4 (GFP-Cla4) treated with FTase inhibitor I. GFP-Cla4 localizes like the wt protein when expressed in BY4741 cells (Additional file 3: Figure S1). Total lysates prepared from GFP-CLA4-transformed cells treated with FTase inhibitor I (Figure 1C, lanes FTI +) or left untreated (Figure 1C, lanes FTI -) were immunoprecipitated (IP) using an anti-GFP antibody
( $\alpha$ GFP) followed by immunoblot analysis. Total lysates were prepared in the presence (Figure 1C, lanes PPA +) or absence of $\lambda$-phosphatase (Figure 1C, lanes PPA -). After normalization against the total amount of Cla4p present in each sample, the amount of phosphorylated Cla4p was calculated (Figure 1D). An average $(n=3)$ increase of $50 \%$ in phosphorylated Cla4p was observed in FTase inhibitor I-treated samples (Figure 1C, lanes FTI + PPA -) compared to controls (Figure 1C, lanes FTI - PPA -).

Thus, we concluded that FTase inhibitor I treatment promotes activation of the PAK kinase Cla4p in yeast cells.

\section{FTI-277 promotes group I PAK expression in HeLa but not in A375MM cells}

PAK kinases are serine/threonine protein kinases that are activated in response to various signalling pathways that regulate proliferation, cell shape and motility in mammalian cells. PAK protein levels have been correlated with proliferation in several human tumors and are known to participate in metastatic processes [22,23]. However, how PAK function relates to FTI efficacy has never been investigated. Human PAKs can be subdivided into two main classes based on their structural characteristics. The current classification separates the yeast PAKs (Cla4, Ste20 and Skm1) from both mammalian PAK classes. However, based on complementation studies performed with PAK family members expressed in ste 20 mutants, the yeast PAKs are considered to be functionally related to group I PAKs [23-25]. Therefore, to determine the effects of FTI on PAKs in tumor cells we first assayed the levels of group I PAKs in HeLa and A375MM melanoma cell lines. HeLa and A375MM were used in these studies as prototypical cancer cell lines with different genotypes (Table 1) [26].

We first measured the basal levels and phosphorylation of group I PAKs and their cytosolic/nuclear distribution in these cell lines upon FTI-277 treatment by automated fluorescence microscopy-based high-content phenotypic profiling using the acquisition and analysis platform of the microscopy station Scan ${ }^{\mathrm{R}}$ (OLYMPUS). In these series of experiments the group I PAK and phosphorylated PAK protein levels were evaluated based on the fluorescence intensity using anti-PAK-C19 $(\alpha \mathrm{Pak})$ or anti-phosphorylated PAK $1 / 2 / 3\left[^{\text {Thr423] }}\right.$ ( $\alpha$ PhoPak) primary antibodies and appropriately fluorescentlyconjugated secondary antibodies, as previously described [10]. These experiments were paralleled by immunoblot analysis for independent validation. We chose to analyse the cells $4 \mathrm{~h}$ and $48 \mathrm{~h}$ after FTI treatment because these time points could be paralleled by proliferation studies.

Image analysis showed that group I PAKs and their phosphorylated forms, hereafter named PAKs and PhoPAKs, respectively, localize in the cytoplasm as well as in the nucleus of HeLa cells (Figure 2A and E, respectively), as 
A

$$
\text { Genes involved in FTI resistance }
$$

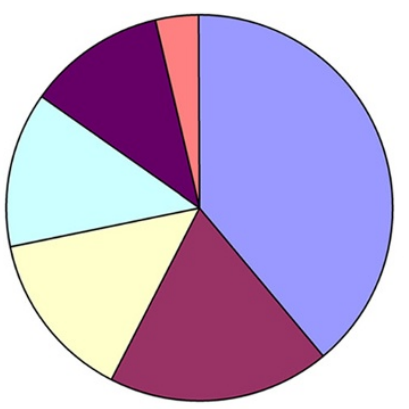

$\square$ metabolic process

$\square$ transport

$\square$ biological process unknown

$\square$ cell cycle

transcription

$\square$ signaling process
B

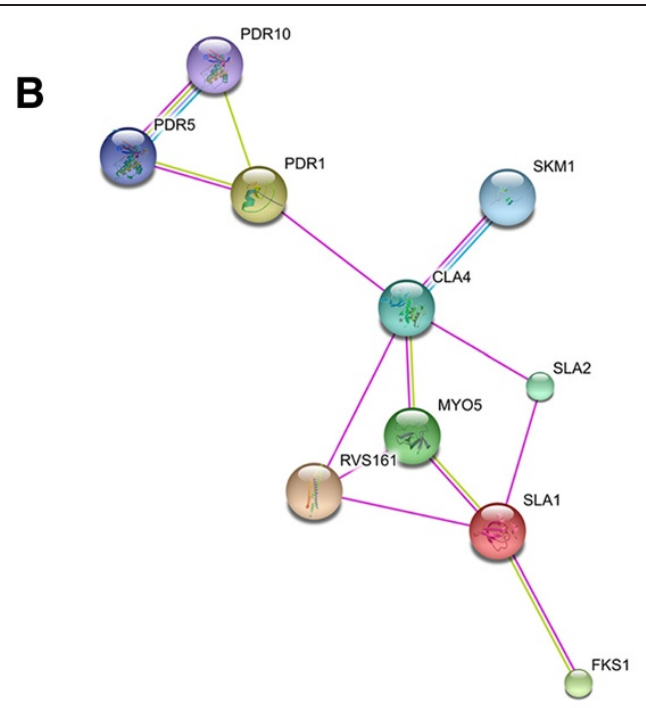

D

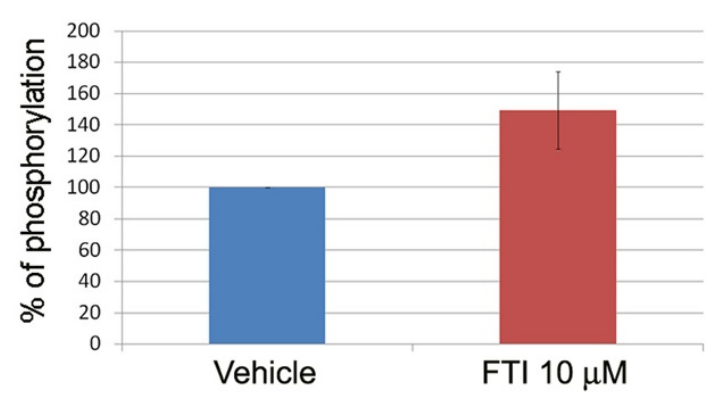

Phosphorylated Cla4-GFP

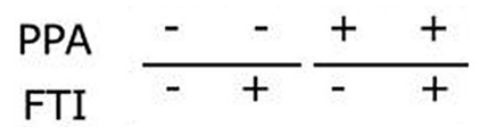

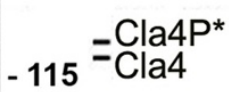

$-180$

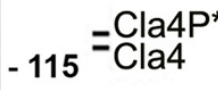

Figure 1 p-21 activated kinases or ABC transporters are among the genes whose deletion increases FTI sensitivity of yeast cells. A. Pie visualization of the 64 genes identified by drug sensitivity screening as putative hits. Super GO Slim tool Biological Process Binning was used for clustering the FTI hypersensitive hits. B. The network analysis of hypersensitive strains carrying deletions of CLA4, SKM1, PDR10 was performed for known and predicted protein-protein interactions using STRING (http://string-db.org/). The evidence view is shown, different line colors represent the types of evidence for the association. High confidence (score 0.700 ) excluding the text mining settings were used as parameters. $\mathbf{C}$. Immunoblot analysis of the immunoprecipitates obtained from BY4741 cells expressing GFP-Cla4. aPhoSer = anti-phosphoserine Q5 antibody; aGFP = anti-GFP antibody. (+) indicates addition, (-) no addition. PPA = phosphatase lambda. FTI =10 $\mu \mathrm{M}$ FTase I inhibitor. Numbers indicate MW. Expected protein positions are indicated. D. The graph shows the relative amount of phosphorylated versus unphosphorylated Cla4 relative to vehicle. The relative protein levels are expressed in percentage (\%). The amount of control (vehicle-treated cells) was considered as 100\%. Error bars indicate means \pm SD of at least 3 replicates $(n=3)$.

Table 1 Panel of tested tumor cell lines

\begin{tabular}{|c|c|c|c|c|c|}
\hline Cell line & Tumor type & Genotype & FTI sensitivity & Source & References \\
\hline HeLa & Cervical & p53 not expressed & Resistant & ECACC & {$[27]$} \\
\hline A375MM & Melanoma & BRaf $f^{1 / 600 E}$ & Resistant & {$[28,29]$} & [28-30] \\
\hline HT29 & Colon & $\begin{array}{l}\text { BRaf } \\
\text { p553600E } \\
\text { R2733H }\end{array}$ & Sensitive & ATCC & {$[26,31,32]$} \\
\hline A549 & Lung & $\mathrm{KRas}^{\mathrm{G} 12 \mathrm{~S}}$ & Sensitive & ATCC & [33] \\
\hline MCF7 & Breast & PI3KCA ${ }^{\text {E545K }}$ & Sensitive & ATCC & [34] \\
\hline
\end{tabular}

Note: wt genes are not indicated. 


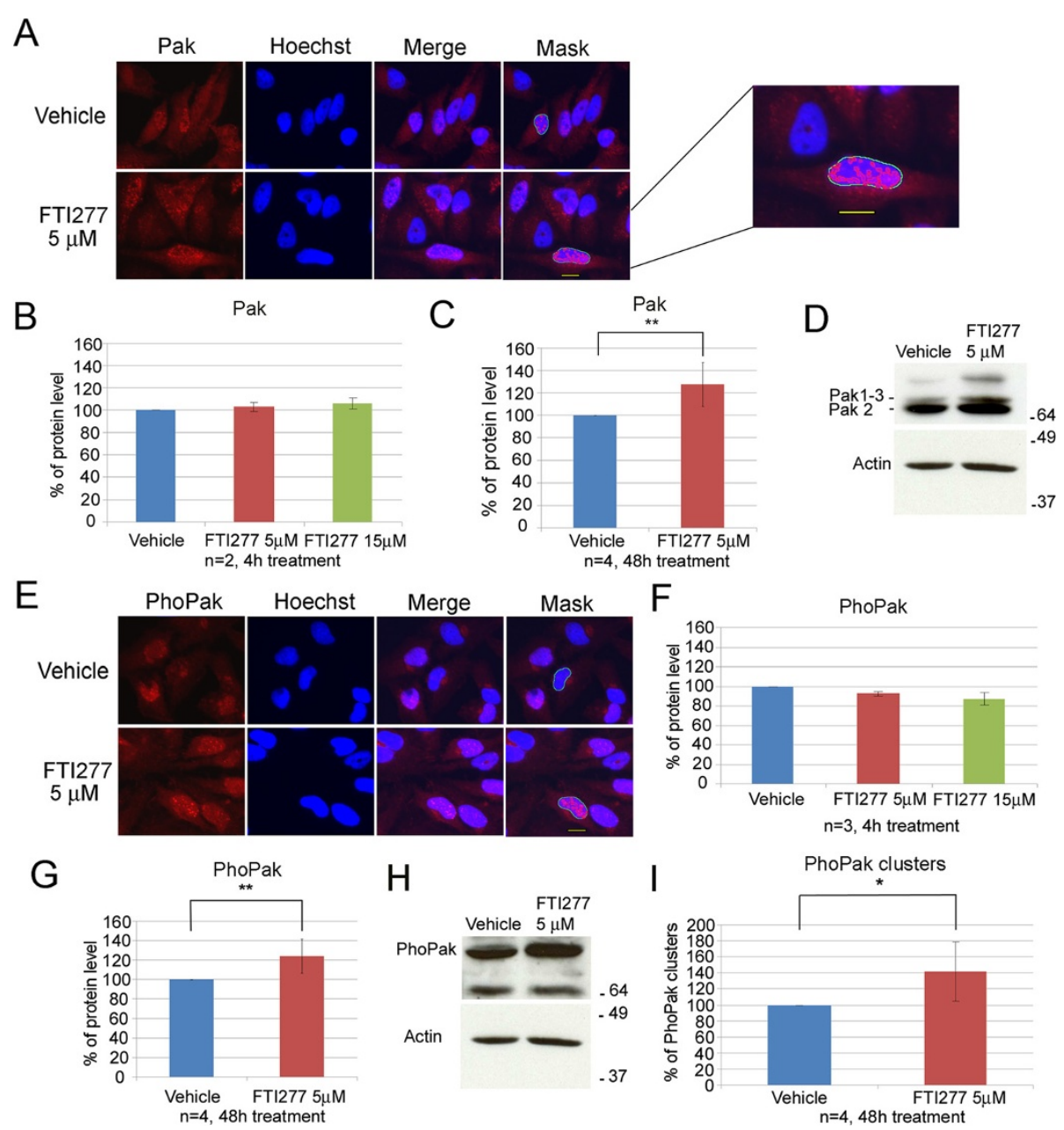

Figure 2 FTI-277 treatment of HeLa cells up-regulates PAKs and phosphorylated PAKs. The statistical significance of the treatments was calculated using t-test: $\mathrm{ns}=$ not significant, $\mathrm{p}$-value $>0.05 ;{ }^{*}=$ significant, $\mathrm{p}$-value $<0.05$; ${ }^{*}$ highly significant $=\mathrm{p}$-value $\left.<0.01\right) . \mathrm{n}=\mathrm{n}$. of biological replicates. Each biological replicate consider the average mean intensity data obtained from analysis of three wells per condition. A. Fluorescently stained HeLa cells treated for $48 \mathrm{~h}$ with the indicated concentration of FTl-277 or DMSO (Vehicle). Panels: PAK = anti-PAK (C19) antibody; Hoechst = nuclear staining; Merge = Hoechst + PAK; Mask: software mask that identifies nuclear PAKs (green), and PAK clusters (spots) within nuclei (red). scale bar $=10 \mu \mathrm{m}$. B. The graph shows the relative amount (\%) of PAKs in the nuclei in $4 \mathrm{~h}$ FTI277-treated cells relative to vehicle, arbitrarily set as $100 \%$. C The graph shows the relative amount (\%) of total PAKs in $48 \mathrm{~h} \mathrm{FTT-277-treated} \mathrm{cells} \mathrm{compared} \mathrm{to} \mathrm{vehicle-treated} \mathrm{cells;} \mathbf{D}$. Immunoblot analysis of total lysates from HeLa cells treated as indicated in C. E. Fluorescently stained HeLa cells treated for $48 \mathrm{~h}$ with the indicated concentration of FTl-277 or DMSO (vehicle). Panels: PhoPak = a-Phospho-PAK1/2/3[pThr423] antibody; Hoechst = nuclear staining; Merge = Hoechst + PhoPak; Mask: software mask that identifies nuclear PhoPaks (green), and PhoPak clusters (spots) within nuclei (red). $\mathbf{F}$. The graph shows the relative amount (\%) of total PhoPaks in $4 \mathrm{~h}$ FTI277-treated cells relative to vehicle-treated cells. G. The graph shows the relative amount of total PhoPaks in $48 \mathrm{~h}$ FTI277-treated cells compared to vehicle-treated cells; $\mathbf{H}$ : immunoblot analysis of total lysates form HeLa cells treated as in $\mathbf{G}$. $\mathbf{I}$. The graph shows the relative number (\%) of PhoPaks spots within the nuclei in $48 \mathrm{~h}$ FTI277-treated cells relative to vehicle-treated cells, which were arbitrarily considered 100\%.

previously described [35-37]. PAKs and PhoPAKs cluster in spots of different dimensions in the nucleus (Figure 2A and $\mathrm{E}$, respectively). After $4 \mathrm{~h}$ treatment with $5 \mu \mathrm{M}$ or $15 \mu \mathrm{M}$ FTI-277, this localization did not change substantially, nor were PAK protein levels affected (Figure 2B) although a slight decrease in the PhoPAK signal was observed (Figure 2F). By contrast, after 48 h of $5 \mu \mathrm{M}$ FTI-277 treatment, a significant $(\mathrm{p} \leq 0.01 \mathrm{n}=4)$ increase in the PAK (Figure 2C) and PhoPAK signal (Figure 2G; $\mathrm{p} \leq 0.01 \mathrm{n}=4$ ) was observed. Immunoblot analysis of samples treated in parallel experiments confirmed these trends (Figure 2D and $\mathrm{H}$, respectively). Moreover, a significant increase $(\mathrm{p} \leq 0.05)$ in PhoPAK clusters within the nuclei was observed (Figure 2I).

We further compared the PAK and PhoPAK localization in HeLa and A375MM cell lines treated and untreated with FTI-277. We observed that PAK localization differs significantly in these cell lines. In 
A375MM melanoma cells, 95\% of PAK proteins reside within the nuclei, while in HeLa cells only $77 \%$ of the protein shows this localization (Figure 3A). Upon FTI277 treatment we failed to observe any effect on PAK protein levels in A375MM melanoma cells. However, as in HeLa cells, the PhoPAK clusters within the nuclei increase significantly over control (Figure 3C panel PhoPak clusters). These data indicate that although the majority of PAK resides within the nuclei in A375MM cells, FTI-277 treatment causes a change from a diffuse to a clustered state of this protein (Figure 3C) but does not affect the overall amount of PAK protein, as occurs in HeLa cells.

To further investigate how FTI-277 treatment affects PAK activity in HeLa cells, we investigated the cell adhesion capabilities of treated versus control cells. It is well established that the interaction of PAKs with the cytosolic PIX-GIT/Paxillin signaling module increases cell motility by promoting focal adhesion (FA) turnover and disassembly $[23,25,38]$. A way to estimate FA assembly is to estimate the amount of vinculin at membranes, as vinculin reduction correlates with reduced FA formation and increased cell migration rates [24,39,40]. Thus, we determined the effects of FTI-277 on cell adhesion by following vinculin recruitment to FAs in HeLa cells, treated with $5 \mu \mathrm{M}$ or $15 \mu \mathrm{M}$ FTI-277 or with vehicle using automated fluorescence microscopy on cells plated in 96-well plates, fixed and processed for image analyses as described above.

As expected, in vehicle-treated samples, vinculin clusters at the membrane were observed, indicating FA formation (Figure 4A panel Vehicle) [39]. Treatment with $5 \mu \mathrm{M}$ or with $15 \mu \mathrm{M}$ FTI-277 for $4 \mathrm{~h}$ resulted in an increased number of FAs containing vinculin compared to control samples (Figure 4B). The time of treatment did not substantially affect this trend (Figure $4 \mathrm{C}$ ). These data indicate that although the overall PAK levels in HeLa cells increase (Figure 2C and G), there are no affects of the cytosolic PAK activity on FAs.

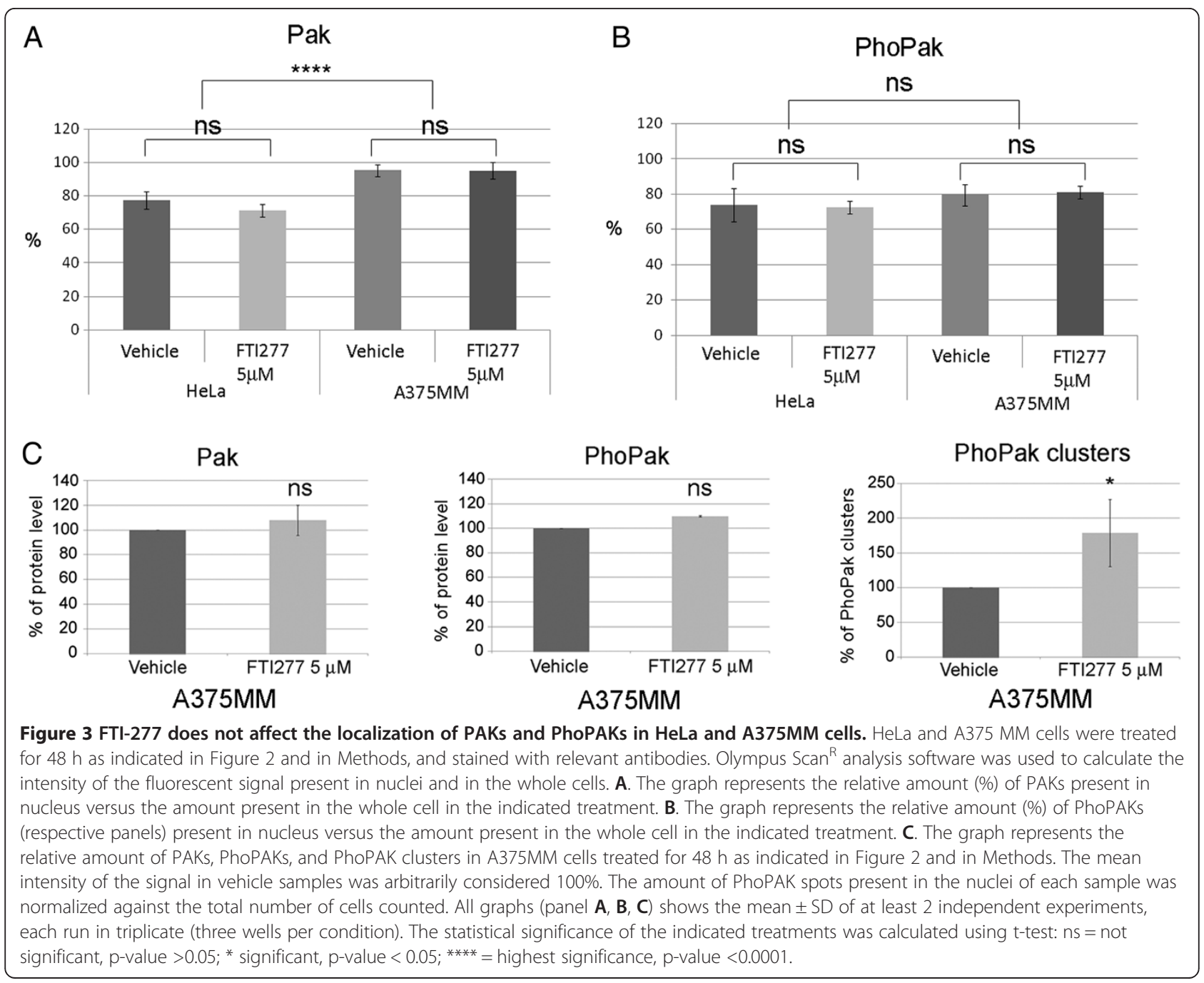




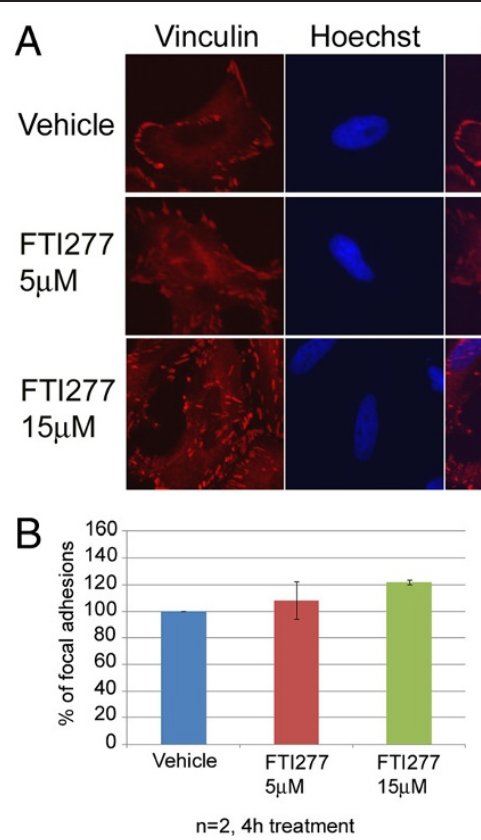

Merge Mask 


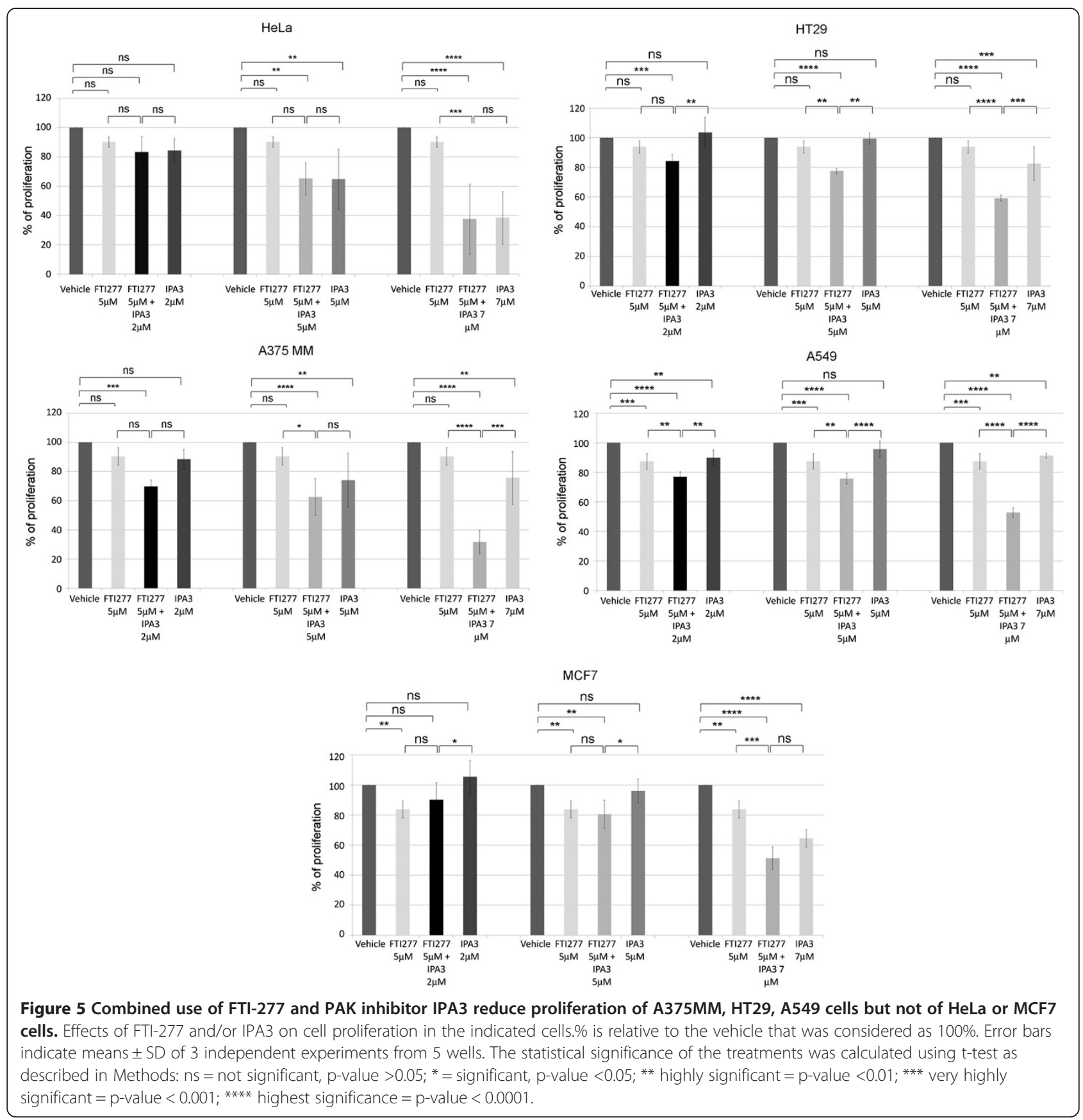

cell lines, while IPA3 is highly effective in inhibiting the proliferation of HeLa and MCF7 cancer cell lines independently of FTI treatment (Figure 5).

To determine if the different proliferative ability of HeLa compared to A375MM cells in the presence of $5 \mu \mathrm{M}$ FTI-277 and $7 \mu \mathrm{M}$ IPA3 was due to an increase in the number of apoptotic cells, we analyzed the percentage of cells that had fragmented nuclei using the $\mathrm{Scan}^{\mathrm{R}}$ analysis software [10]. FTI-277 treatment of A375MM cells led to a significant increase in the number of apoptotic cells, which was reduced when the cells were co-treated with IPA3, suggesting that IPA3 has a protective effect against apoptosis (Additional file 5: Figure S3, respective panels). These data indicate that IPA3 counteracts the pro-apoptotic activity of FTI277 in this cell line. By contrast, no major effects were observed on HeLa cells using either drug alone or in combination (Additional file 5: Figure S3, respective panels).

To estimate the number of senescent cells, we measured the mean area of cells compared to control [44] after FTI-277 treatment in the presence or absence of 
different concentrations of IPA3 using the $\operatorname{Scan}^{\mathrm{R}}$ analysis software. We observed that the combined treatment of FTI-277 and IPA3 resulted in a statistically significant increase in the overall cellular area in both HeLa and A375MM cells compared to vehicle-treated cells but not compared to FTI-277 treated cells (Figure 6).

\section{Discussion}

Group 1 PAKs are key players in cellular mechanisms that are important for transformation, tumor progression and metastatic processes [23]. Here we show that the combined use of group I PAK inhibitors and FTI-277 exerts a potent anti-proliferative action in melanoma, colon and
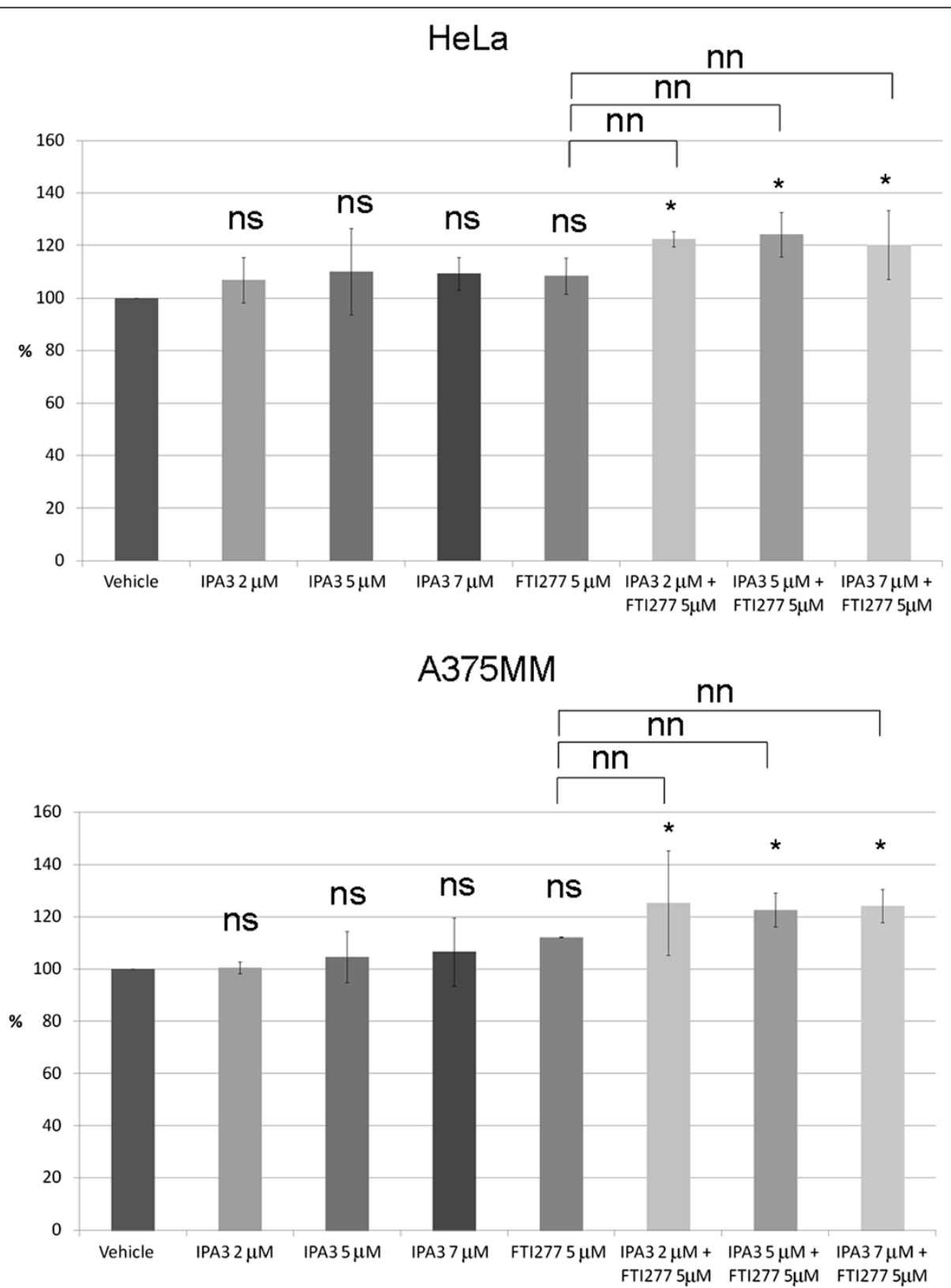

Figure 6 Combined treatment of FTI-277 and IPA3, but not FTI-277 alone, increases the cell size of HeLa and A375MM cells. HeLa and A375MM cells were treated for $48 \mathrm{~h}$ as indicated in Figures 2, 3 and in Methods, and stained with relevant antibodies. Olympus Scan ${ }^{R}$ analysis software was used to calculate the area of each cell counted. The graph represents the relative area (\%) of cells treated as indicated for HeLa and A375MM cells (respective panels) with cells treated with vehicle, arbitrarily set at 100\%. The graph shows the mean \pm SD of 2 independent experiments, each run in triplicate (three well per condition). More than 73 cells for A375MM and 573 cells for HeLa cells were counted per sample in each experiment. Results of t-test are shown above the graph: ns: no significant deviation from vehicle, $p$-value $>0.05 ;{ }^{*} p$-value $<0.05$; nn: no significant deviation from FTl-277, p-value $>0.05$. 
lung cancer cell lines. Given the refractory to conventional treatments of these tumors, these findings open the possibility of using FTIs in combinatorial therapies with PAK inhibitors for these aggressive tumors. Importantly, our data show also that the underlying mechanism of how PAK down-regulation and FTIs exerts an anti-proliferative action on eukaryotic cells is evolutionarily conserved.

Our genome-wide FTI sensitivity screen data indicate that deleting the $\mathrm{ABC}$ transporter gene PDR10 is one way to increase FTI sensitivity in yeast cells. ABC transporters constitute a large family of proteins that act as detoxification pumps in yeast as well as in mammalian cells [45]. They are known to participate in drug resistance in various ways and to be up-regulated in several tumors $[20,45,46]$. The data reported here support previous yeast genome-wide expression profiling studies showing that the ABC transporter Pdr5 and its transcriptional regulator Pdr1 respond to FTI drug intake in yeast cells by up-regulating their activity [10]. Importantly it has previously shown that Pdr5 recycling from the plasma membrane to endosomes depends on END4/ SLA1, which interacts directly with the PAK kinase Cla4 $[20,21]$. Recent epistasis studies indicate that Pdr10 has a complementary function with Pdr5. Moreover, Pdr10 function depends on Pdr5, Pdr12, Lem3 and sphingolipids [47-49]. Taken together these data, our expression and chemical profiling of yeast cells treated with FTI inhibitor I, it can be envisaged that it exists a functional network that connects FTI uptake at the plasma membrane by $\mathrm{ABC}$ transporters acting in sphingolipid metabolism and PAK activation. Consistent with this, we showed previously that FTase inhibitor I promotes Pdr5 recycling from the plasma membrane [10]. The existence of a functional network that connects FTI uptake, $\mathrm{ABC}$ transporter recycling and PAK activity is also supported by the phenotypic analysis of yeast cells lacking of the PAK CLA4 $(\Delta$ cla4): a drastic reduction in drug resistance and in the transcription of the $\mathrm{ABC}$ transporter PDR5 was shown $[47,50]$. Here we show that the PAK Cla4 is activated in FTase inhibitor I-treated yeast cells. A role for some classes of the $A B C$ transporter family in FTI resistance in mammalian tumors has been previously suggested by genome-wide expression profiling studies performed with the FTI Tipifarnib $[8,9,17]$. However, the large number of $\mathrm{ABC}$ transporters encoded by the human genome, their different distribution in different cancer cell lines, and their redundant functions [45], makes it difficult to identify which of them might be specifically involved in FTI uptake in the tumors studied in this study.

The data obtained here indicate that in the presence of FTI-277, PAKs sustain proliferation of melanoma, colon and lung cancer cell lines, but unlikely of HeLa or MCF7 cell lines. Proliferation inhibition caused by the combined use of FTI-277 and IPA3 ranged from 40\% for HT29 cells to $68 \%$ for A375MM cells. In case of HT29 and A549 cells, even the lowest concentration $(2 \mu \mathrm{M})$ of IPA3 used significantly inhibited proliferation when combined FTI-277 compared to IPA3 alone. The poor response of HeLa and MCF7 tumor cell lines to the combined use of the PAK inhibitor and FTI-277, compared to the significant responsiveness of A375MM, HT29 and A549 cell lines, must reside in the mechanism that determines how FTI peptidomimetics act as antiproliferative drugs in these cell lines. A375MM and HT29 are mutated in BRafV600 and A549 carry a K-Ras mutation while HeLa cells have wt Ras. It is known that A375MM cells rely on the activation of two main signaling pathways that sustain proliferation: RAF-MEK-ERK (MAPK) and PI3K-AKT-mTOR (AKT) signalling. The FTI inhibitor Lonafarnib acts through inhibition of mTOR signaling independently of MAPK or AKT activation [14]. Given these data it is conceivable that FTImediated PAK activation acts in synergy with MAPK and AKT pathways or is part of these pathways in these cell lines. Thus not only the mechanism by which PAK down-regulation exerts an anti-proliferative action in the presence of FTIs must be a basic and well-conserved process in the evolution, but also these data show that the combined use of FTIs and PAK inhibitors potently act as antiproliferative drugs in unrelated aggressive cancers characterized by constitutive activation of MAPK and AKT pathways. This latter view is also supported by the recently reported function of PAK1 in stimulation of colorectal proliferation by gastrins via multiple signalling pathways involving activation of ERK, AKT, and $\beta$ catenin [51]. Increased p21-activated kinase-1 expression is associated with invasive potential in uveal melanoma [52]. Thus, it is conceivable to think that the contemporaneous shut-down of either the RAF-MEK-ERK (MAPK) or PI3K-AKT signaling pathway might at the basis of the susceptibility of HT29, A375MM and A549 cells to FTI and PAK inhibitors.

All together our mammalian data substantially confirm the yeast data showing that PAK inhibition cooperates with FTIs in inhibiting proliferation of eukaryotic cells. The susceptibility of the A549 lung cancer cell line, which harbours a K-Ras mutation, to the combined use of IPA3 and FTI-277 is of particular interest, given the aggressiveness of current treatments for lung cancer. It has been previously shown that A549 cells treated with FTI-277 are blocked at the G2/M transition [19]. Interestingly, it was observed that antibodies developed against a specific C-terminal Ste20/PAK homologue facilitates the release of Xenopus oocytes from G2 arrest [53]. Given the observation that a combination of FTI277 and IPA3 significantly increases the proportion of senescent A375MM cells, we propose that the combined 
effects of FTI-277 and PAK inhibitor IPA3 might similarly release A549 cells from the FTI-mediated G2/M block and promote senescence. To try to answer why the combinatorial use of IPA3 and FTI-277 does not reduce HeLa cell proliferation, we analysed the activation status and the intracellular localization of PAKs in HeLa and A375MM cell lines. However, none of the parameters measured correlated with the different effects that PAK inhibitors have on the respective proliferation abilities. In HeLa cells the effects of FTI-277 on FA assembly and vinculin recruitment are consistent with the anti-proliferative function of FTIs and with the view that cytosolic PAK/PIX/GIT module activation is not involved in the FTI-mediated PAK activation response.

\section{Conclusions}

This work firmly establishes that PAK inactivation combined with FTI treatment has a potent anti-proliferative action on yeast as well as melanoma, colon and lung cancer cells. Further work will be required to elucidate how PAK inhibitors aid FTI anti-proliferative action in these tumor cell lines. Based on the yeast data [10], we suggest that $\mathrm{ABC}$ transporter recycling, consequent to FTI uptake, is the initial signal that activate PAK.

\section{Methods}

Yeast strains, plasmid constructs, media and growth conditions

Strains and oligonucleotides are listed in Tables 2 and 3, respectively. Media, yeast transformation and genetic manipulation as well as molecular procedures were as described previously [54]. Unless otherwise specified, yeast cells were grown at $28^{\circ} \mathrm{C}$ with agitation in YPD medium or in SD medium lacking the appropriate amino acid for plasmid selection as previously described [54]. To construct GFP-tagged Cla4, the Cla4 ORF was amplified by PCR from genomic DNA with the oligonucleotides listed in Table 3 using the High Fidelity Polymerase Chain Reaction kit (Roche). The PCR product was digested XmaI/EcoRI and ligated into the vector pUG34 as described previously [54].

\section{Reagents and antibodies}

FTase inhibitor I (Cat.No 344510) and FTI-277 (Cat. No. 344555) were purchased from Merck-Calbiochem and were used according to the manufacture's protocols as described in [10]. The p-21 activated kinase inhibitor IPA3

\section{Table 2 Strains}

\begin{tabular}{lll}
\hline Strains & Genotype & Source \\
\hline BY4741 wt & MATa, leu2, ura3, his3, met15 & EUROSCARF \\
$\begin{array}{l}\text { Deletion strain collection } \\
\text { research genetics }\end{array}$ & MATa haploid deletion mutants & {$[55]$} \\
\hline
\end{tabular}

Table 3 Oligonucleotides

\begin{tabular}{ll}
\hline Cla4Xmal-Fw & AAATCCCGGGATATGTCTCTTTCAGCTGCAGCGA \\
Cla4EcoRI-Rv & AATAGAATTCGATATGCTTATAGAAATAGTTGTG \\
\hline
\end{tabular}

(1,1'-Disulfanediyldinaphthalen-2-ol, Cat.No. I2285) was purchased from Sigma. Antibodies are listed in Table 4.

\section{Yeast protein extraction, immunoprecipitation and immunoblot analysis}

BY4741 cells carrying the plasmid GFP-Cla4 pUG34 were grown in the presence or absence of $10 \mu \mathrm{M}$ FTase inhibitor I in selective media as previously described [10]. Typically, the drug was added to cultures diluted to an $\mathrm{OD}_{600}=0.08$ and the cells were harvested at $\mathrm{OD}_{600}=0.6$. To prepare crude extracts for phosphoprotein detection, the cells were diluted 1:1 in Stop Mix (0.9\% NaCl, $1 \mathrm{mM} \mathrm{NaN}_{3} 10 \mathrm{mM}$ EDTA, $50 \mathrm{mM} \mathrm{NaF}$ ), washed once in Stop Mix, and resuspended in Lysis Buffer (50 mM Tris- $\mathrm{HCl}$ pH 7.5, $0.1 \mathrm{mM}$ EDTA, $1 \mathrm{mM}$ DTT, $1 \mathrm{mM}$ PMSF) containing protease inhibitor and phosphatase inhibitor tablets (Roche) as described [56]. Crude extracts were obtained by the glass beads method and glycerol was added to a final concentration of $20 \%$. The protein concentration was determined using the Bradford assay as described [54]. Immunoprecipitation and immunoblot analysis were performed as described previously [57]. Results were analysed and quantified on a Pharos FX densitometer using the Quantity One software (BioRad).

\section{Drug sensitivity screening of yeast cells}

The screen was performed using $10 \mu \mathrm{M}$ FTase inhibitor I on the barcoded yeast deletion strain collection

\section{Table 4 Antibody list}

\begin{tabular}{lll}
\hline Name & Manufacture/code & Protein target \\
\hline a-GFP & Roche, 11814460001 & GFP \\
$\begin{array}{l}\text { a-PhosphoSerine } \\
\text { Antibody Q5 }\end{array}$ & Qiagen, 37430 & $\begin{array}{l}\text { Serine-phosphorylated } \\
\text { proteins }\end{array}$ \\
$\begin{array}{l}\text { a-PAK (C19) } \\
\text { a-Phospho-PAK1/2/3 }\end{array}$ & Santa Cruz, Sc881 & PAK 1/2/3 \\
[pThr423] & Pigma, P7746 & Phopshorylated \\
a-Actin & Sigma, A2066 & Actin \\
$\begin{array}{l}\text { a-Vinculin, clone FB11 } \\
\text { AlexaFluor 546 Goat }\end{array}$ & Chemicon, MAB1624 & Vinculin \\
$\begin{array}{l}\text { a-Rabbit IgG } \\
\text { AlexaFluor 546 Goat } \\
\text { a-Mouse IgG }\end{array}$ & Invitrogen, A11030 & Mouse IgG \\
$\begin{array}{l}\text { AlexaFluor 488 Goat } \\
\text { a-Rabbit IgG }\end{array}$ & Invitrogen, A11034 & Rabbit IgG \\
$\begin{array}{l}\text { AlexaFluor 488 Chicken } \\
\text { a-Mouse IgG }\end{array}$ & Invitrogen, A21200 & Mouse IgG \\
\hline
\end{tabular}


generated by the S. cerevisiae deletion consortium [58] for all genes whose deletion has a viable phenotype in yeast. The screening was performed according to the procedures and protocols described in [55]. The cut-off for the hits was set at an average $\log _{2}$ ratio of $0.5(\mathrm{p} \leq 0.05)$. Gene clustering and classification was performed using the GO Term tool of the SGD database (www.yeastgenome. org). Binning by biological process was performed with a maximal confidence setting as previously described [10]. Data mining was performed using NCBI databases (http:// www.ncbi.nlm.nih.gov/pubmed/). Gene network analysis and network graphic representation was performed using STRING (version 8.3) software that collects data from known and predicted protein interaction databases freely available at http://string.embl.de. The interactions include direct (physical) and indirect (functional) associations; they are derived from Genomic Context, High-throughput Experiments, Coexpression Previous Knowledge. Confidence setting for data analysis was set at 0.7 (high confidence value).

\section{Human cell culture and drug treatments}

Media, serum and reagents for tissue culture were purchased from $\mathrm{GIBCO}^{\mathrm{mix}}$ (Invitrogen). HeLa cells (ECACC) were grown in MEM supplemented with $10 \%$ foetal calf serum (FCS), $2 \mathrm{mM}$ L-glutamine, penicillin, streptomycin and non-essential amino acids, at $37^{\circ} \mathrm{C}$ in $5 \%$ $\mathrm{CO}_{2}$. A375MM cells (kindly provided by Dr. Roberto Buccione, CMNS, Italy $[28,29]$ ) were grown in DMEM/ F12 (1:1) supplemented with 10\% FCS, 2 mM L-glutamine, penicillin and streptomycin at $37^{\circ} \mathrm{C}$ in $5 \% \mathrm{CO}_{2}$. HT29 cells (ATCC) and A549 cells (ATCC) were grown in DMEM supplemented with 10\% FCS, $2 \mathrm{mM} \mathrm{L-glu-}$ tamine, penicillin and streptomycin, at $37^{\circ} \mathrm{C}$ in $5 \% \mathrm{CO}_{2}$. MCF7 cells (ATCC) were grown in MEM supplemented with 10\% FCS, non-essential amino acids, insulin $10 \mu \mathrm{g} /$ $\mathrm{ml}$ (Sigma), $\mathrm{NaHCO}_{3} 1 \mathrm{mM}$, penicillin and streptomycin at $37^{\circ} \mathrm{C}$ in $5 \% \mathrm{CO}_{2}$.

\section{FTI compounds and treatment}

The FTI-277 treatment of HeLa and A375MM cell lines for image analysis and proliferation assays were performed as previously described [10] with the indicated drug concentrations or, as mock reactions in parallel experiments, with the vehicle DMSO.

\section{PAK phosphorylation inhibitor}

IPA3 was added, at the indicated concentration, alone or combined with FTI-277 or the vehicle (DMSO). Cells were incubated for the indicated times, as previously described [10].

HeLa cells for cell extract preparation were plated in a 6-well plate, left to attach overnight and treated with the indicated concentration of FTI-277 or vehicle (DMSO).
After $48 \mathrm{~h}$, cells were scraped off, collected, washed in phosphate-buffered-saline (PBS) $1 \times$ and lysed in a modified RIPA buffer $[25 \mathrm{mM}$ Tris- $\mathrm{HCl} \mathrm{pH} 7.5$, $150 \mathrm{mM} \mathrm{NaCl}, 1 \% \mathrm{NP}-40,1 \% \mathrm{Na}$-deoxycholate, $0.1 \%$ SDS, $1 \mathrm{mM}$ EDTA, $30 \mathrm{mM} \beta$-glycerophosphate, $10 \mathrm{mM}$ $\mathrm{NaF}, 5 \mathrm{mM}$ Na orthovanadate, $1 \mathrm{mM}$ PMSF, $1 \times$ Protein tablet inhibitor (Roche)]. Lysates were centrifuged for $10 \mathrm{~min}, 8000 \times \mathrm{g}$, and then boiled in SDS-loading buffer prior to SDS-PAGE and immunoblot analysis, as previously described [10].

\section{Immunofluorescence}

Immunofluorescence image analysis was performed in cells plated in 96-well Greiner-Bio-One plates using the $\mathrm{Scan}^{\mathrm{R}}$ microscopy platform (Olympus) with a $20 \times$ objective as previously described [10,59]. Briefly, treated and control samples were plated in 96-well plates and left to attach for $24 \mathrm{~h}$ before drug(s) treatments. Drugs were added to the medium at the indicated concentration and incubation continued for the indicated times (4 h or $48 \mathrm{~h}$ ). After treatment, cells were washed in PBS $1 \times$ and fixed in PBS $1 \times$ containing 4\% paraformaldehyde for $10 \mathrm{~min}$. Cells were permeabilized for $30 \mathrm{~min}$ in blocking buffer $[0.05 \%$ saponin, $0.5 \%$ bovine serum albumin (BSA), $50 \mathrm{mM} \mathrm{NH}_{4} \mathrm{Cl}$ and $0.02 \% \mathrm{NaN}_{3}$ ]. Fixed cells were then incubated with the primary antibody, washed three times in PBS $1 \times$ and incubated with the appropriate fluorescently-conjugated secondary antibody. The nuclei were stained with Hoechst, prior to being washed three times in PBS $1 \times$ and inspected. High content image analysis was typically based on data obtained from at least 3 wells/sample. Image segmentation and analysis was performed using the inbuilt $\mathrm{Scan}^{\mathrm{R}}$ analysis software (Olympus) and based on a mask identifying the nuclei. The signal intensity values measured for each channel per sample were based on at least 12 images/well. Samples were swapped in the plate order in different biological replicates (typically $n \geq 2$ ) to avoid local intensity signal drift as previously described [10]. All results are expressed as mean \pm standard deviation (SD).

\section{Statistical analysis}

Unpaired T-tests were used to assess differences between treatment vs. control samples. In the graphs the controls were normalized to 100 while changes in expression levels of treatments were analyzed as differences from normalized controls. P-values less than 0.05 were considered significant. Statistical analyses were performed using SAS $^{\circledR}$ Language (Release 9.2. Cary, NC, USA; 2002-2008).

\section{Proliferation assays of human cells}

MTS-based proliferation assays was performed using CellTiter $96^{\circledR}$ AQueous One Solution Cell (Promega) according to the manufacturer's protocol. Typically, each 
cell line was plated in 5 wells and left to attach overnight in a 96-well plate (Falcon). Subsequently, they were treated with $5 \mu \mathrm{M}$ FTI-277 and/or IPA3 at a concentration of $2 \mu \mathrm{M}, 5 \mu \mathrm{M}$, or $7 \mu \mathrm{M}$. The IPA3 compound was added at the same time as the FTI-277 or the vehicle (DMSO) in parallel experiments. The number of living cells was measured at $\mathrm{T}=0$ and at $\mathrm{T}=48 \mathrm{~h}$. Briefly, $20 \mu \mathrm{l}$ of Cell Titer was dispensed in each well containing $100 \mu \mathrm{l}$ medium. The plate was incubated at $37^{\circ} \mathrm{C}$ in $5 \%$ $\mathrm{CO}_{2}$ sterile chamber for three hours, and the amount of formazan was measured reading the absorbance at $490 \mathrm{~nm}$ with a plate reader (BioTek Instruments). The results are the mean of three independent experiments.

\section{Additional files}

Additional file 1: Table S1. The results of chemical profiling of yeast cells treated with FTase Inhibitor I. The table shows the genes whose deletion generates a hypersensitive phenotype to $10 \mu \mathrm{M}$ FTase Inhibitor I treatment after chemical profiling of approximately 4700 barcoded yeast deletion strains. Genes discussed in more detail in this paper are highlighted in orange.

Additional file 2: Table S2. Genes involved in transport and the genes that respond to chemical stimulus mediate the sensitivity of yeast cells to FTI. The table shows the biological processes associated with the 64 genes whose deletion generates a hypersensitive phenotype to FTase inhibitor I. The genes were binned using GO Slim Mapper binning by Biological Process (SGD, Saccharomyces Genome Database at yeastgenome.org). Each gene is listed by a gene identifier, the biological process assigned to the gene by SGD, the relative frequency of genes that have the same process compared to the total number of genes considered, and compared to the total number of genes that carry out that process in the whole yeast genome, and the names of the genes belonging to each group.

Additional file 3: Figure S1. Cla4-GFP localizes like the wt Cla4 protein in BY4741 cells. Representative images of exponentially growing BY4741 wt cells carrying the plasmid Cla4-GFP pUG34 treated for $1 \mathrm{~h}$ with $10 \mu \mathrm{M}$ FTase Inhibitor I (panel FTI) or with vehicle (panel Vehicle) as indicated in the text in the appropriate selective media. Microscopy inspection and image acquisition was performed as previously described using a $60 x$ objective [10].

Additional file 4: Figure S2. A375MM cells are highly sensitive to 20 HM IPA3. A375 MM cells were treated for $48 \mathrm{~h}$ with the indicated compounds as indicated in Figure 5 and in Methods. \% is relative to the vehicle arbitrarily considered as 100\%. Error bars are means \pm SD of 2 independent experiments calculated from 4 wells/sample.

Additional file 5: Figure S3. Combined treatment of FTI-277 and IPA3 does not induce apoptosis in HeLa and A375MM cells. HeLa and A375MM cells were treated for $48 \mathrm{~h}$ as indicated in Figures 2, 3 and in Methods, and stained with Hoechst. Olympus Scan ${ }^{R}$ analysis software was used to calculate the number of apoptotic cells based on the total intensity Hoechst signal present within the nuclear region as described in [10]. More than 573 HeLa cells and 73 A375MM cells were counted per sample in each experiment. The graph represents the relative amount (\%) of apoptotic cells in treated versus vehicle-treated cells, arbitrarily set at $100 \%$. The graph shows the mean \pm SD of 2 independent experiments, each run in triplicate (three wells per condition). Results of t-test are shown above the graph: ns: no significant deviation from vehicle, $\mathrm{p}$-value $>0.05 ;{ }^{*} \mathrm{p}$-value $<0.05 ;{ }^{* *} \mathrm{p}$-value $<0.01$

\section{Abbreviations}

FTI: Farnesyl-transferase inhibitor; FTase: Farnesyl-transferase;

PAK: P21-activated kinase; PhoPAK: Phosphorylated p21-activated kinase.

\section{Competing interests}

The authors declare to have no conflict of interests.

\section{Authors' contributions}

GP and ARW devised and performed the experiments and wrote the manuscript. MGM performed biochemical experiments. DDG technical assistance. GL statistical analysis. ABP and CB performed deletion library screening and related data analysis. All authors read and approve the final manuscript.

\section{Authors' information}

GP, post-doc. MGM, Ph.D. student. DDG, technician. GL, post-doc. ABP associate researcher. CB, Professor. ARW Aggregate Professor.

\section{Acknowledgments}

We are deeply indebted to Dr. Cathal Wilson (Tigem, Italy) for a critical reading of the manuscript, Dr. Fabio Pellegrini (Consorzio Mario Negri Sud, IT) for suggestions related to the statistical analysis, and the members of the HT/HCA Facility of the Consorzio Mario Negri Sud (http://www.negrisud.it/it/ricerca/servizi/ htmicroscopy/f for help with the microscopy work. This work was supported partially by AIRC grant IG-1964 and by Fondazione Negri Sud. Maria Giovanna Mosca fellowship was partially supported by Telethon grant GGP08143.

\section{Author details}

'Department of Translational Pharmacology, Consorzio Mario Negri Sud, S. Maria Imbaro, Italy. ${ }^{2}$ Department of Molecular Genetics, Donnelly Centre, University of Toronto, 160 College Street, Toronto, Ontario M5S 3E1, Canada. ${ }^{3}$ Department of Clinical Pharmacology and Epidemiology, Consorzio Mario Negri Sud, S. Maria Imbaro, Italy. ${ }^{4}$ Department of Biology, University of Rome Tor Vergata, Rome, Italy.

Received: 21 December 2012 Accepted: 26 July 2013 Published: 6 August 2013

\section{References}

1. Gibbs JB, Oliff A: The potential of farnesyltransferase inhibitors as cancer chemotherapeutics. Annu Rev Pharmacol Toxicol 1997, 37:143-166.

2. Sebti SM, Hamilton AD: Farnesyltransferase and geranylgeranyltransferase I inhibitors and cancer therapy: lessons from mechanism and bench-to -bedside translational studies. Oncogene 2000, 19:6584-6593.

3. Tamanoi F, Mitsuzawa H: Use of yeast for identification of farnesyltransferase inhibitors and for generation of mutant farnesyltransferases. Methods Enzymol 1995, 255:82-91.

4. Casey PJ, Seabra MC: Protein prenyltransferases. J Biol Chem 1996, 271:5289-5292.

5. Appels NM, Beijnen JH, Schellens JH: Development of farnesyl transferase inhibitors: a review. Oncologist 2005, 10:565-578.

6. Karp JE, Lancet JE: Tipifarnib in the treatment of newly diagnosed acute myelogenous leukemia. Biologics 2008, 2:491-500.

7. Berndt N, Hamilton AD, Sebti SM: Targeting protein prenylation for cancer therapy. Nat Rev Cancer 2011, 11:775-791.

8. Katayama K, Yoshioka S, Tsukahara S, Mitsuhashi J, Sugimoto Y: Inhibition of the mitogen-activated protein kinase pathway results in the downregulation of P-glycoprotein. Mol Cancer Ther 2007, 6:2092-2102.

9. Medeiros BC, Landau HJ, Morrow M, Lockerbie RO, Pitts T, Eckhardt SG: The farnesyl transferase inhibitor, tipifarnib, is a potent inhibitor of the MDR1 gene product, P-glycoprotein, and demonstrates significant cytotoxic synergism against human leukemia cell lines. Leukemia 2007, 21:739-746.

10. Porcu G, Wilson C, Di Giandomenico D, Ragnini-Wilson A: A yeast-based genomic strategy highlights the cell protein networks altered by FTase inhibitor peptidomimetics. Mol Cancer 2010, 9:197.

11. Basso AD, Kirschmeier P, Bishop WR: Lipid posttranslational modifications. Farnesyl transferase inhibitors. J Lipid Res 2006, 47:15-31.

12. Robak T, Szmigielska-Kapłon A, Pluta A, Grzybowska-Izydorczyk O, Wolska A, Czemerska M, Wierzbowska A: Novel and emerging drugs for acute myeloid leukemia: pharmacology and therapeutic activity. Curr Med Chem 2011, 18:638-666.

13. Sparano JA, Moulder S, Kazi A, Coppola D, Negassa A, Vahdat L, Li T, Pellegrino C, Fineberg S, Munster P, Malafa M, Lee D, Hoschander S, Hopkins U, Hershman D, Wright JJ, Kleer C, Merajver S, Sebti SM: Phase II trial of tipifarnib plus neoadjuvant doxorubicin-cyclophosphamide in patients with clinical stage IIB-IIIC breast cancer. Clin Cancer Res 2009, 15:2942-2948. 
14. Niessner H, Beck D, Sinnberg T, Lasithiotakis K, Maczey E, Gogel J, Venturelli S, Berger A, Mauthe M, Toulany M, Flaherty K, Schaller M, Schadendorf D, Proikas-Cezanne T, Schittek B, Garbe C, Kulms D, Meier F: The farnesyltransferase inhibitor lonafarnib inhibits mTOR signaling and enforces sorafenib-induced apoptosis in melanoma cells. J Invest Dermatol 2011, 131:468-479.

15. Kho Y, Kim SC, Jiang C, Barma D, Kwon SW, Cheng J, Jaunbergs J, Weinbaum C, Tamanoi F, Falck J, Zhao Y: A tagging-via-substrate technology for detection and proteomics of farnesylated proteins. Proc Natl Acad Sci U S A 2004, 101:12479-12484.

16. Raponi M, Belly RT, Karp JE, Lancet JE, Atkins D, Wang Y: Microarray analysis reveals genetic pathways modulated by tipifarnib in acute myeloid leukemia. BMC Cancer 2008, 4:56.

17. Raponi M, Lancet JE, Fan H, Dossey L, Lee G, Gojo I, Feldman EJ, Gotlib J, Morris LE, Greenberg PL, Wright JJ, Harousseau JL, Löwenberg B, Stone RM, De Porre $P$, Wang Y, Karp JE: A 2-gene classifier for predicting response to the farnesyltransferase inhibitor tipifarnib in acute myeloid leukemia. Blood 2008, 111:2589-2596.

18. Deacon SW, Beeser A, Fukui JA, Rennefahrt UE, Myers C, Chernoff J, Peterson JR: An isoform-selective, small-molecule inhibitor targets the autoregulatory mechanism of p21-activated kinase. Chem Biol 2008, 15:322-331.

19. Miquel K, Pradines A, Sun J, Qian Y, Hamilton AD, Sebti SM, Favre G: GGTI298 induces G0-G1 block and apoptosis whereas FTI-277 causes G2-M enrichment in A549 cells. Cancer Res 1997, 57:1846-1850.

20. Egner R, Mahé Y, Pandjaitan R, Kuchler K: Endocytosis and vacuolar degradation of the plasma membrane-localized Pdr5 ATP-binding cassette multidrug transporter in Saccharomyces cerevisiae. Mol Cell Biol 1995, 15:5879-5887.

21. Drees BL, Sundin B, Brazeau E, Caviston JP, Chen GC, Guo W, Kozminski KG, Lau MW, Moskow JJ, Tong A, Schenkman LR, McKenzie A 3rd, Brennwald P, Longtine M, Bi E, Chan C, Novick P, Boone C, Pringle JR, Davis TN, Fields S, Drubin DG: A protein interaction map for cell polarity development. J Cell Biol 2001, 154:549-571.

22. Dummler B, Ohshiro K, Kumar R, Field J: Pak protein kinases and their role in cancer. Cancer Metastasis Rev 2009, 28:51-63.

23. Molli PR, Li DQ, Murray BW, Rayala SK, Kumar R: PAK signaling in oncogenesis. Oncogene 2009, 28:2545-2555.

24. Hofmann C, Shepelev M, Chernoff J: The genetics of Pak. J Cell Sci 2004 117:4343-4354.

25. Arias-Romero LE, Chernoff J: A tale of two Paks. Biol Cell 2008, 100:97-108.

26. Sepp-Lorenzino L, Ma Z, Rands E, Kohl NE, Gibbs JB, Oliff A, Rosen N: A peptidomimetic inhibitor of farnesyl:protein transferase blocks the anchorage-dependent and -independent growth of human tumor cell lines. Cancer Res 1995, 55:5302-5309.

27. Böhnke A, Westphal F, Schmidt A, El-Awady RA, Dahm-Daphi J: Role of p53 mutations, protein function and DNA damage for the radiosensitivity of human tumor cells. Int J Radiat Biol 2004, 80:53-63.

28. Baldassarre M, Pompeo A, Beznoussenko G, Castaldi C, Cortellino S, McNiven MA, Luini A, Buccione R: Dynamin participates in focal extracellular matrix degradation by invasive cells. Mol Biol Cell 2003, 14:1074-1084.

29. Kozlowski JM, Hart IR, Fidler IJ, Hanna N: A human melanoma line heterogeneous with respect to metastatic capacity in athymic nude mice. J Natl Cancer Inst 1984, 72:913-917.

30. Sumimoto $H$, Imabayashi $F$, Iwata T, Kawakami Y: The BRAF-MAPK signaling pathway is essential for cancer-immune evasion in human melanoma cells. J Exp Med 2006, 203:1651-1656.

31. Lee J, Lee I, Han B, Park JO, Jang J, Park C, Kang WK: Effect of simvastatin on cetuximab resistance in human colorectal cancer with KRAS mutations. J Natl Cancer Inst 2011, 103:674-688.

32. Haupt S, di Agostino S, Mizrahi I, Alsheich-Bartok O, Voorhoeve M, Damalas A, Blandino $G$, Haupt Y: Promyelocytic leukemia protein is required for gain of function by mutant p53. Cancer Res 2009, 69:4818-4826.

33. Yoon YK, Kim HP, Han SW, Oh do Y, Im SA, Bang YJ, Kim TY: KRAS mutant lung cancer cells are differentially responsive to MEK inhibitor due to AKT or STAT3 activation: implication for combinatorial approach. Mol Carcinog 2010, 49:353-362.

34. Wu G, Xing M, Mambo E, Huang X, Liu J, Guo Z, Chatterjee A, Goldenberg D, Gollin SM, Sukumar S, Trink B, Sidransky D: Somatic mutation and gain of copy number of PIK3CA in human breast cancer. Breast Cancer Res 2005, 7:R609-R616.
35. Li F, Adam L, Vadlamudi RK, Zhou H, Sen S, Chernoff J, Mandal M, Kumar R p21-activated kinase 1 interacts with and phosphorylates histone $\mathrm{H} 3$ in breast cancer cells. EMBO Rep 2002, 3:767-773.

36. Zhao ZS, Lim JP, Ng YW, Lim L, Manser E: The GIT-associated kinase PAK targets to the centrosome and regulates Aurora-A. Mol Cell 2005, 20:237-249.

37. Ando Y, Yasuda S, Oceguera-Yanez F, Narumiya S: Inactivation of Rho GTPases with Clostridium difficile Toxin B Impairs Centrosomal Activation of Aurora-A in G2/M Transition of HeLa Cells. Mol Biol Cell 2007, 18:3752-3763.

38. Zhao ZS, Manser E, Loo TH, Lim L: Coupling of PAK-interacting exchange factor PIX to GIT1 promotes focal complex disassembly. Mol Cell Biol 2000, 20:6354-6363.

39. Ziegler WH, Liddington RC, Critchley DR: The structure and regulation of vinculin. Trends Cell Biol 2006, 16:453-460.

40. Saunders RM, Holt MR, Jennings L, Sutton DH, Barsukov IL, Bobkov A, Liddington RC, Adamson EA, Dunn GA, Critchley DR: Role of vinculin in regulating focal adhesion turnover. Eur J Cell Biol 2006, 85:487-500.

41. Doisneau-Sixou SF, Cestac P, Faye JC, Favre G, Sutherland RL: Additive effects of tamoxifen and the farnesyl transferase inhibitor FTI-277 on inhibition of MCF-7 breast cancer cell-cycle progression. Int J Cancer 2003, 106:789-798.

42. Zhao ZS, Manser E: Do PAKs make good drug targets? F1000 Biol Rep 2010, 2:70.

43. Flaiz C, Chernoff J, Ammoun S, Peterson JR, Hanemann CO: PAK kinase regulates Rac GTPase and is a potential target in human schwannomas. Exp Neurol 2009, 218:137-144.

44. Kumazaki T, Robetorye RS, Robetorye SC, Smith JR: Fibronectin expression increases during in vitro cellular senescence: correlation with increased cell area. Exp Cell Res 1991, 195:13-19.

45. Fletcher Jl, Haber M, Henderson MJ, Norris MD: ABC transporters in cancer: more than just drug efflux pumps. Nat Rev Cancer 2010, 10:147-156.

46. Wu CP, Hsieh CH, Wu YS: The emergence of drug transporter-mediated multidrug resistance to cancer chemotherapy. Mol Pharm 2011, 8:1996-2011.

47. Rockwell NC, Wolfger $\mathrm{H}$, Kuchler K, Thorner J: ABC transporter Pdr10 regulates the membrane microenvironment of Pdr12 in Saccharomyces cerevisiae. J Membr Biol 2009, 229:27-52.

48. Rogers B, Decottignies A, Kolaczkowski M, Carvajal E, Balzi E, Goffeau A: The pleitropic drug $A B C$ transporters from Saccharomyces cerevisiae. J Mol Microbiol Biotechnol 2001, 3:207-214.

49. Pomorski T, Lombardi R, Riezman H, Devaux PF, van Meer G, Holthuis JC: Drs2p-related P-type ATPases Dnf1p and Dnf2p are required for phospholipid translocation across the yeast plasma membrane and serve a role in endocytosis. Mol Biol Cell 2003, 14:1240-1254

50. Souid AK, Gao C, Wang L, Milgrom E, Shen WC: ELM1 is required for multidrug resistance in Saccharomyces cerevisiae. Genetics 2006, 173:1919-1937.

51. Huynh N, Yim M, Chernoff J, Shulkes A, Baldwin GS, He H: p-21-Activated kinase 1 mediates gastrin-stimulated proliferation in the colorectal mucosa via multiple signaling pathways. Am J Physiol Gastrointest Liver Physiol 2013, 304:G561-G567.

52. Pavey S, Zuidervaart W, van Nieuwpoort F, Packer L, Jager M, Gruis N, Hayward $\mathrm{N}$ : Increased p21-activated kinase-1 expression is associated with invasive potential in uveal melanoma. Melanoma Res 2006, 16:285-296.

53. Faure S, Vigneron S, Dorée M, Morin N: A member of the Ste20/PAK family of protein kinases is involved in both arrest of Xenopus oocytes at G2/ prophase of the first meiotic cell cycle and in prevention of apoptosis. EMBO J 1997, 16:5550-5561.

54. Wagner W, Bielli P, Wacha S, Ragnini-Wilson A: Mlc1p promotes septum closure during cytokinesis via the IQ motifs of the vesicle motor Myo2p EMBO J 2002, 21:6397-6408.

55. Parsons AB, Lopez A, Givoni IE, Williams DE, Gray CA, Porter J, Chua G, Sopko R, Brost RL, Ho CH, Wang J, Ketela T, Brenner C, Brill JA, Fernandez GE, Lorenz TC, Payne GS, Ishihara S, Ohya Y, Andrews B, Hughes TR, Frey BJ, Graham TR, Andersen RJ, Boone C: Exploring the mode-of-action of bioactive compounds by chemical-genetic profiling in yeast. Cell 2006, 126:611-625.

56. Kamada Y, Jung US, Piotrowski J, Levin DE: The protein kinase C-activated MAP kinase pathway of Saccharomyces cerevisiae mediates a novel aspect of the heat shock response. Genes Dev 1995, 9:1559-1571.

57. Casavola EC, Catucci A, Bielli P, Di Pentima A, Porcu G, Pennestri M, Cicero DO, Ragnini-Wilson A: Ypt32p and Mlc1p bind within the vesicle binding region of the class $\mathrm{V}$ myosin Myo2p globular tail domain. Mol Microbiol 2008, 67:1051-1066. 
58. Winzeler EA, Shoemaker DD, Astromoff A, Liang H, Anderson $\mathrm{K}$, Andre B, Bangham R, Benito R, Boeke JD, Bussey H, Chu AM, Connelly C, Davis K, Dietrich F, Dow SW, El Bakkoury M, Foury F, Friend SH, Gentalen E, Giaever G, Hegemann JH, Jones T, Laub M, Liao H, Liebundguth N, Lockhart DJ, Lucau-Danila A, Lussier M, M'Rabet N, Menard P, et al: Functional characterization of the $S$. cerevisiae genome by gene deletion and parallel analysis. Science 1999, 285:901-906.

59. Sacco F, Gherardini PF, Paoluzi S, Saez-Rodriguez J, Helmer-Citterich M, Ragnini-Wilson A, Castagnoli L, Cesareni G: Mapping the human phosphatome on growth pathways. Mol Syst Biol 2012, 8:603.

doi:10.1186/1476-4598-12-88

Cite this article as: Porcu et al.: Combined p21-activated kinase and farnesyltransferase inhibitor treatment exhibits enhanced antiproliferative activity on melanoma, colon and lung cancer cell lines. Molecular Cancer 2013 12:88.

\section{Submit your next manuscript to BioMed Central and take full advantage of:}

- Convenient online submission

- Thorough peer review

- No space constraints or color figure charges

- Immediate publication on acceptance

- Inclusion in PubMed, CAS, Scopus and Google Scholar

- Research which is freely available for redistribution 